\title{
A diagnose not to miss: Rotatory Atlantoaxial subluxation in emergency service
}

\section{Kaçırıllmaması gereken bir tanı: Acill serviste Rotatuvar Atlantoaksiyel subluksasyon!}

Umut OCAK ${ }^{1}$, Pinar ESER OCAK ${ }^{2}$

Department of Emeroency Medicine, Yuksekova State Hospital, Hakkari, TURKEY.

${ }^{2}$ Department of Neurosurgery, Yuksekova State Hospital, Yuksekova, Hakkari, TURKEY.

Corresponding author: Umut OCAK, Department Of Emergency Medicine, Bozok University Medical Faculty, 66200. Yozgat, TURKEY

E-mail: drumutocak@gmail.com,umutocak@yahoo.com

Received/Accepted: January 07, 2016/ February 12, 2016

Conflict of interest: There is not a conflict of interest.

\begin{abstract}
SUMMARY
Objective: The objective of this study is to take attention to atlantoaxial subluxations especially in pediatric population that may be misdiagnosed in the emergency services easily. When diagnosed early in the emergency services, it may be corrected with ease and the treatment is more likely to be conservative.
\end{abstract}

Method: Seven patients with atlantoaxial rotatory subluxation (AARS), between ages of 5 and 13, who admitted to our emergency service between 1 July 2013 - 1 September 2014 were examined retrospectively.

Results: All patients were treated conservatively with bed rest, muscle relaxants and rigid cervical collar. None of them needed surgery.

Conclusions: Atlantoaxial rotatory subluxation (AARS) is one of the main types of cervical spine anomalies seen in pediatric patients and is a rare condition that is often misdiagnosed and therefore incorrectly managed especially in emergency services. The diagnosis requires a high index of suspicion. Many pediatric cervical spine injuries can be treated with external immobilization and AARS is almost always reducible. Pediatric population is prone to upper spine injuries due to ligamentous laxity and AARS should always be kept in mind especially in emergency services.

Key words: Atlantoaxial subluxation, torticollis, diagnosis, emergency service

ÖZET

Amaç: Bu çalışmanın amacı, acil servislerde özellikle pediyatrik popülasyonda kolaylıkla yanlış tanı alabilecek atlantoaksiyel subluksasyonlara dikkat çekmektir. Acil servislerde erken tanı konulduğunda; kolaylikla düzeltilebilir ve konservatif tedavi ihtimali daha yüksektir.

Yöntem: Acil servisimize 1 Temmuz 2013-1 Eylül 2014 arasında başvuran; 5 ve 13 yaşları arasinda atlantoaksiyel rotatuvar subluksasyonlu (AARS) 7 hasta retros pektif olarak incelendi.

Bulgular: Tüm hastalar yatak istirahati, kas gevşetici ve sert boyunluk ile konservatif olarak tedavi edildi. Hiçbirinde cerrahi ihtiyacı olmadi.

Sonuç: Atlaktoaksiyel rotatuvar subluksasyon (AARS) pediyatrik hastalarda görülen başlıca servikal omurga anomali tiplerinden biridir ve sıklıkla yanlış tanı konulan nadir bir durumdur; bu nedenle özellikle acil servislerde yanlış yönetilebilmektedir. Tanı için yüksek oranda şüphe duymak gerekmektedir. Pekçok pediyatrik servikal omurga yaralanması eksternal immobilizasyon ile tedavi edilebilir ve AARS hemen daima redükte edilebilirdir. Pediyatrik popülasyon ligamentöz laksite nedeni ile üst omurga yaralanmalarma meyillidir ve AARS özellikle acil servislerde her zaman akilda tutulmalıdır.

Anahtar Kelimeler: atlantoaksiyel subluksasyon, tortikollis, tan1, acil servis 


\section{INTRODUCTION}

$1.5 \%$ of the pediatric trauma patients represent with a cervical spine injury [1]. According to the unique anatomical and biomechanical features of the pediatric spine; they are prone to especially upper cervical spinal ligamentous rather than bony injuries. The understanding of this unique anatomic and biomechanical features of the pediatric spine is essential not to dismiss this rare but unfortunately potentially fatal cases especially admitting to emergency rooms.

AARS is usually seen in pediatric population especially following head trauma and respiratory tract infections (Grisel Syndrome). The clinical manifestation includes 'cock-robin' position (lateral flexion and rotation to other side) of the neck with painfull torticollis and limited rotation (Fig.1).

Early diagnose is the most important fact in the management of AARS. As it is usually seen after trauma, generally the emergency department is the first admission center. Although there is not a concensus among the authors, there is a tendency to conservative theraphy especially for acute and neurologically intact cases. Delayed diagnose may even seen in acute traumatic patients. Persistent torticollis and malposition with external immobilization, recurrent cases and delayed diagnose requires surgical intervention. In this study, we aimed to call attention to the importance of early diagnosis of AARS especially in emergency services. With the aim to clarify the key points of the early diagnosis, we investigated 7 pediatric patients admitting to our emergency service and treated conservatively between 1 July 2013 and 1 September 2014 (Table $1)$. etiologic properties of the patients.

\begin{tabular}{|c|c|c|c|c|}
\hline Patient (n=7) & Gender & Age & Etiology & Symptom \\
& & & & \\
\hline 1 & M & 8 & Spontaneous & 4 days \\
\hline 2 & F & 7 & Spontaneous & 2 days \\
\hline 3 & F & 11 & Spontaneous & 3 days \\
\hline 4 & M & 6 & Traumatic (MVA) & 2 hours \\
\hline 5 & M & 8 & Traumatic (FFH) & 1 day \\
\hline 6 & F & 6 & Post-infectious & 2 days \\
\hline 7 & F & 9 & Post-infectious & 13 days \\
\hline & & & & \\
\hline
\end{tabular}

Abbreviations: $\mathrm{M}=$ male, $\mathrm{F}=$ female, $\mathrm{MVA}=$ motor vehicle accident, $\mathrm{FFH}=$ fall from height.

\section{MATERIAL AND METHODS}

We retrospectively examined 3 male and 4 female patients between the ages of 5 and 13 (mean $=7.8$ years), admitting to Yuksekova State Hospital Emergency Service between 1 July 2013 and 1 September 2014. All of the patients had painfull torticollis with cock-robin position. They were diagnosed by physical and neurological examination and the diagnosis were confirmed by cervical computed tomography (CT) scan. All the patients were neurologically intact. Axial and coronal CT scans were the inclusion criteria in this study. The atlantoaxial rotatory subluxations were classified according to the Fielding and Hawkins classification (Table 2)

Table 2 Summary of Fielding and Hawkins 
classification of atlantoaxial rotatory subluxation.

\begin{tabular}{|c|l|}
\hline Type I & $\begin{array}{r}\text { Rotation without anterior displacement } \\
\text { with the dens acting as a pivot }\end{array}$ \\
\hline Type II & Rotation with anteiror displacement of 3-5 \\
ADI $=3.1-5 \mathrm{~mm}$ & $\mathrm{~mm}$ with the intact facet acting as a pivot \\
\hline Type III & $\begin{array}{l}\text { Rotation with anterior displacement more } \\
\text { than 5 mm with the displacement of both } \\
\text { ADI }>5 \mathrm{~mm}\end{array}$ \\
\hline Type IV & Rotation with posterior displacement \\
\hline
\end{tabular}

All of the patient were hospitalized; muscle relaxants and analgesics were ordered. They were all manipulated under sedation with gentle reduction by neurosurgery department and rigid cervical collar was fitted for 6 weeks. Neurological status was recorded every day. The patients were recalled for regular revisits after discharge.

\section{RESULTS}

Three of the 7 patients admittence were traumatic and 4 were spontaneous. Two of the spontaneous cases had upper respiratory tract infection history. Symptom duration was between 2 hours and 13 days (mean=3.5 days). All the patients had painfull torticollis and limitation in neck movements. The patients neurological and physical examinations were normal. Traumatic cases were pure servical trauma and no additional trauma was diagnosed. All of them were type 1 subluxation according to the Fielding and Hawkins classification [2].

After hospitilization, all the patients were taken to operation room and rigid Philadelphia collars were fitted after gentle manipulation under sedation by neurosurgeon. Post-infectious cases were consulted with pediatry department but since there were no evidence of infection, antibiotheraphy was not ordered.

Neurological status was recorded every day. All the patients remarked no neck pain after the manipulation. Bed rest, analgesics and muscle relaxants were ordered. The success of the treatment was confirmed by control CT scan. After discharge, patient were revisited periodically every month. They used the Philadelphia collar for 6 weeks. We did not establish pain or neurological abnormality in the follow-up period.

\section{DISCUSSION}

Pediatric spine has idiosyncratic features according to the different biomechanical characteristics such as increased mobility and tendency to distraction and subluxation injuries according to the ligamentous laxity, greater head/body ratio, horizontally oriented facets, immature bony structure and weak neck muscles. In young children cervical spine is the most frequently affected part of the spine, especially the cranio-cervical junction [2]. In children younger than 8 years, occipitoatlantoaxial complex and pure ligamentous injuries are more often while osseous lesions are more often after this period $[1,3,4,5]$.

The atlantoaxial joint provides approximately $60 \%$ of neck rotation with the supports of transvers and alar ligaments $[6,7]$. The loss of atlantoaxial stability results in the loss of normal articulation referring the term of 'atlantoaxial dislocation' [8].

Atlantoaxial rotatory subluxation is one of the main types of cervical spine anomalies seen in pediatric patients. Although rotatory atlantoaxial subluxation (AARS) is a rare condition, it is the most frequent manifestation of the atlantoaxial dislocation in pediatric population.

The etiology depends on traumatic, congenital and infectious causes mostly. Grisel syndrome, firstly described by Sir Charles Bell in 1830, generally occurs in childhood causing a non-traumatic atlantoaxial subluxation according to the upper respiratory tract infections. Distention of the facet capsules and inflammatory streching affect of the synovium on transverse ligament is thought to be the cause of Grisel syndrome [9]. High speed motor vehicle accidents are the most frequent traumatic causes 
[10]. There are also cases reported with Down and asymptomatic moyamoya syndrome [11] and juvenil spondyloarthritis [12] in the literature. Underlying congenital anomalies that are associated with craniocervical junction anomalies are prone to develop atlantoaxial dislocation. Goldenhar syndrome, Morquio syndrome (mucopolysaccha-ridosis type IV) and spondyloepi-physeal displasia are the examples of skeletal dysplasias that are mentioned with atlantoaxial subluxation [13]. There is also a familial case report published [14]. Recent otolaryngeal surgery history such as adenoidectomy, tonsillectomy is also an important risc factor that sould be questioned during consultation.

The clinical manifestation includes 'cockrobin' position (lateral flexion and rotation to other side) of the neck with painfull torticollis and limited rotation (Fig.1). Frequently, neurological examination is normal. Complete neurologic injury causes death at this level. Delayed myelopathy according to AARS is also reported even after a long latency period [15]. Being an acute and painfull stituation or traumatic events directs patients to the emergency departments firstly, most of the time.

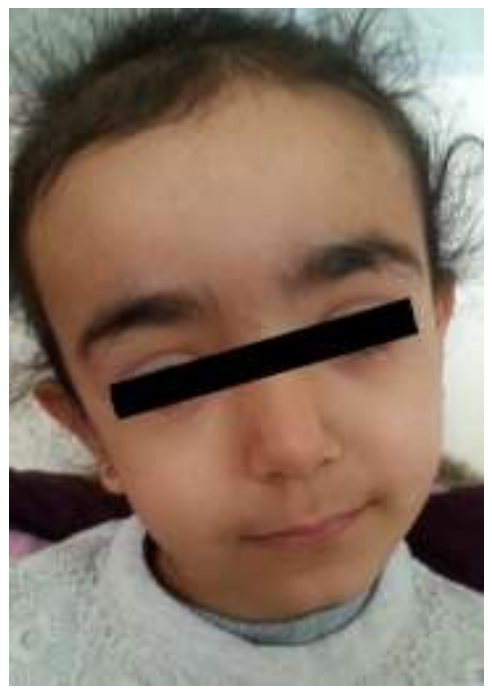

Fig. 1: A 6 year-old patient demonstrating 'cock-robin' position.
Atlantoaxial dislocations were firstly classified by Greenberg in two categories as 'reducible' and 'irreducible' [16]. Subsequently, AARS were classified into 4 subtypes by Fielding and Hawkins according to the direction of the dislocation (Table 1). Type I and II lesions are predominantly seen in pediatric population [17]. As the treatment mostly depends on the stability, type I lesions in which the transverse ligament is intact is tought to be stable lesions.

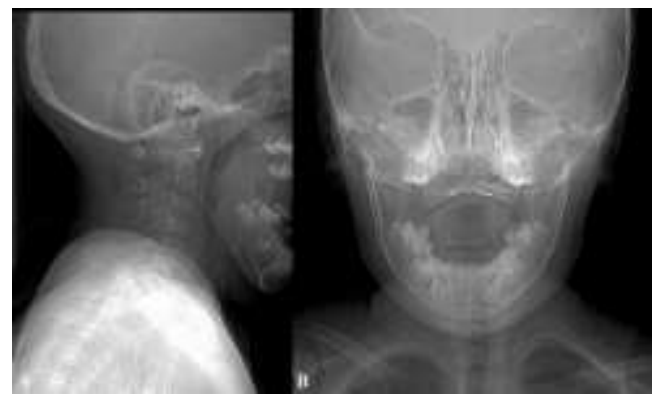

Fig. 2: A. Lateral X-ray graphy demonstrating ADI (atlantodental interval) under $4 \mathrm{~mm}$.

B. Open mouth odontoid graphy demonstrating the loss of odontoid asymmetry (White lines).

There are several methods and imaging modalities for diagnosing atlantoaxial dislocation. Conventional X-ray, computed tomography and magnetic resonanse imagings are commonly used. Expanded (anterior) atlantodental interval (ADI) and lateralized odontoid (LO) are the major radiographic signs of dislocation (Fig.2B). ADI is described as the space between the anterior margin of dens and the closest point of the anterior arch of $\mathrm{Cl}$ on lateral $\mathrm{X}$-ray. ADI should be under $4 \mathrm{~mm}$ for children younger than 15 years. Abnormally increased ADI can be an indirect indicator of transverse ligament disruption [18]. Yet, rotatory dislocation type I may not have widened ADI (Fig.2A) and normal people may have LO [19]. Therefore, conventional radiographs are not always helpful in the diagnosis of AARS. In the open mouth odontoid graphy, loss of asymmetry between the lateral masses of $\mathrm{C} 1$ and odontoid is thought to be rotatory subluxation of atlantoaxial joint. Rotation of $\mathrm{C} 1$ vertebra and the relationship between $\mathrm{C} 1$ and odontoid can be best represented by $\mathrm{CT}$ 
scan, likely (Fig.3A). Also the lateralized odontoid can be viewed by coronal CT images (Fig.3B). In the cases who have anterior or posterior displacement of $\mathrm{C} 1$ more than $3 \mathrm{~mm}$ should also be scanned with MRI in order to check the transverse ligament. Duan et al stated that, 3dimentional computed tomography visualising the articulating facet displacement of lateral atlantoaxial joint is an adequate way of correcting not only the AARS diagnose but also the type and extend of subluxation [20] (Fig.4A, 4B, 4C, 4D).

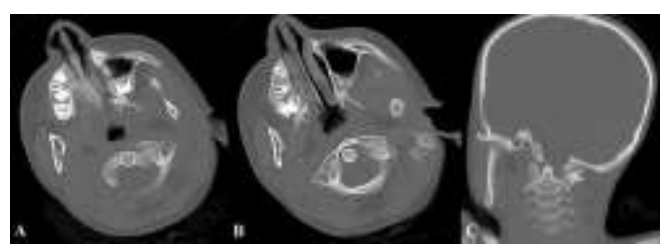

Fig. 3: A and B. Axial CT scan slices demonstrating the rotatory subluxation of atlantoaxial joint.

C. Coronal CT scan slices demonstrating the loss of odontoid asymmetry.

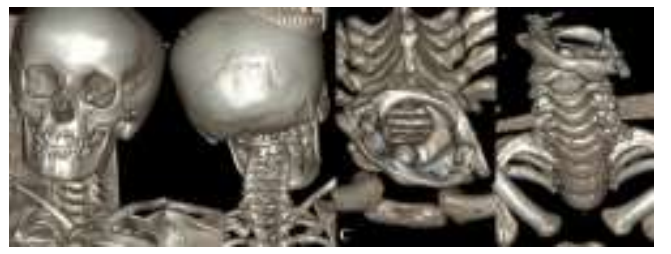

Fig. 4: A and B. 3-D CT scan slices demonstrating 'cock-robin' position.

C and D. 3-D CT scan slices demonstrating the articulating facet displacement of lateral atlantoaxial joint.

Rotatory deformities are generally easily managed and corrected, especially when early diagnosed, and are occasionally recurrent and resistent to conservative theraphy. Although there is not a consensus on management, there is a tendency for non-operative strategies. In 1977, Fielding and Hawkins reported their 17 cases, 13 of whom where treated with surgical arthrodesis. They roecommended traction followed by external immobilizatin for 3 months. The risk of recurrence was found greater with longstanding fixation greater than 3 months and these patients needed fusion [21]. In 1989,
Philips and Hensinger reported their series of 23 children. They used halter traction and halo traction subsequently when the initial one was ineffective. The 3 recurrent cases went to surgical stabilization. They stated that; symptom duration was the most important factor for the management strategy. Children whose symptoms lasting less than a week see benefits from soft collar theraphy and bed rest while the ones whose symptoms lasting 1 week-1 month needed traction and subsequently postreduction immobilization for 4-6 weeks [22]. In 1998, Subach reported his series of 20 pediatric patients. They used halter traction for 15 , collar and medical theraphy for 5 patients. Subsequently, 6 of them needed surgical intervension for the causes of recurrence or unsuccessful reduction [23]. In 2005, Pang and Lee cited their series of 50 cases. They used traction for all of the patients. Halter traction was initiated for the ones whose symptom duration were under 3 months and cranial traction for the rest. 19\% of the patients needed surgical fusion [24]. In 2012, Beier et al represented their case of 40 children. In their series initial cervical collar theraphy was sufficient in 21 of the patients. One of them needed halter traction for the fail of collar theraphy. Seven patients went directly to halter and 2 to halo traction. Both of the halo vested patients needed surgery subsequently. They stated that patients presenting acutely without neurologic defisits can benefit from collar theraphy while the subacute ones are more prone to surgical theraphy [25]. Ciftdemir et al also reported case series of 8 patients in 2012 and professed that non-operative treatment is successful in patients with an early diagnosis [26]. Chechic et all represented their 5 pediatric cases in 2012. They stated that conservative treatment by gradual and prolonged traction without manipulative reduction in cases especially diagnosed in 3 weeks and without neurological defisits is a successful method in AARS [27].

Most of the patients with Grisel's syndrome have a surgery history, mostly otolaryngeal [28, 29]. To preclude irreversible neurologic defisits, treatment should be given as soon as possible. [30] 
Once diagnosed, the treatment is conservative including bed rest, external fixation and medical theraphy including antibiotics and muscle relaxants. Delayed diagnose may cause failure in conservative theraphy and surgery may be required [31, 32].

In our cases, 3 of the 7 patients were traumatic and brought to the emergency service of our hospital immediately. The 4 remaining were non-traumatic; but being an acute and painfull condition with the decreased head motion that had forced the parents to the emergency service. All the patients were detected for cervical spine pathology and consulted by neurosurgery department. Spontaneous cases were questioned for an upper respiratory tract infection, surgery, congenital anomalies, arthritis and cryptogenic disease in detail. The diagnosis were confirmed immediately by radiologic methods. All the patients who had type I dislocation according to Fielding and Hawkins classification were treated conservatively as indicated in the literature.

\section{REFERENCES}

1. Patel JC, Tepas JJ III, Mollitt DL, Pieper P. Pediatric cervical spine injuries: defining the disease. J Pediatr Surg 2001; 36: 373-6.

2. Bilston LE, Brown J. Pediatric spinal injury type and severity are age and mechanism dependent. Spine 2007; 32: 2339-47.

3. Brown RL, Brunn MA, Garcia VF. Cervical spine injuries in children: a review of 103 patients treated consecutively at a level 1 pediatric trauma center. J Pediatr Surg 2001; 36: 1107-14.

4. Cirak B, Ziegfeld S, Knight VM, Chang D, Avelline AM, Padias CN. Spinal injuries in children. J Pediatr Surg 2004; 39: 607-12.

5. Kokoska ER, Keller MS, Rallo MC, Weber TR. Characteristics of pediatric cervical spine injuries. J Pediatr Surg 2001; 36: 100-5.

6. Pang D, Li V. Atlantoaxial rotatory fixation: Part 1- biomechanics of normal rotation at the atlantoaxial joint in children. Neurosurgery 2004; 55: 614-26.

7. Rinaldi I, Mullins WJ Jr, Delaney WF, Fitzer PM, Tornberg DN. Computerized tomographic demonstration of rotational atlanto-axial fixation. Case report. J Neurosurg 1979; 50: 115-9.

8. Yang SY, Boniello AJ, Poorman CE, Chang AL, Wang S, Passias PG. A review of the diagnosis and treatment of atlantoaxial dislocations. Global spine J 2014; 4: 197-210.

9. Wetzel FT, La Rocca H. Grisel's Syndrome. Clin Orthop Relat Res 1989; 240: 141-51.

10. Marshall KW, Koch BL, Egelhoff JC. Air bag-related deaths and serious injuries in children: injury patterns and imaging findings. Am J Neuroradiol 1998; 19: 15991607.

11. Lee KY, Lee KS, Weon YC. Asymptomatic moyamoya syndrome, atlantoaxial subluxation and basal ganglia calcification in a child with Down syndrome. Korean J Pediatr 2013; 561: 540-3.

12. Muscal E, Satyan K B, Jea A. Atlantoaxial subluxation as an early manifestation in an adolescent with undifferentiated spondyloarthritis: a case report and review of the literature. Journal of medical case reports 2011; 5: 275.

13. Song D, Maher CO. Spinal disorders associated with skeletal dysplasias and syndromes. Neurosurg Clin N Am 2007; 183: 499-514.

14. Singh AP, George A, Steele N, Madhavan P. A case of familial pediatric atlantoaxial subluxation. Ann R Coll Surg Engl 2012; 94 : e179-81.

15. Takamatsu R, Takahashi H, Yokoyama Y, Terajima F, Inoue Y, Fukutake KA, Wada A. Case of delayed myelopathy caused by 
atlantoaxial subluxation without fracture. Case Rep Orthop. 2013; 2013: 421087.

16. Greenberg AD. Atlanto-axial dislocations. Brain 1968; 91: 65584.

17. Harty JA, Lenehan B, O'Rourke SK. Odontoid lateral mass asymmetry: do we overinvestigate? Emerg Med J 2005; 22: 625-7.

18. Powers B, Miller MD, Kramer RS, Martinez S, Gehweiler JA Jr. Traumatic anterior atlantooccipital dislocation. Neurosurgery 1979; 4: 12-7.

19. Panjabi MM, Oda T, Crisco JJ 3rd, Oxland TR, Katz L, Nolte LP. Experimental study of atlas injuries. I. Biomechanical analysis of therie mechanisms and fracture patterns. Spine 1991; 16: S460-5.

20. Duan S, Huang X, Lin Q, Chen G. Clinical significance of articulating facet displacement of lateral atlantoaxial joint on 3D CT in diagnosing atlantoaxial subluxation. J Formos Med Assoc 2007; 106: 840-6.

21. Fielding JW, Hawkins RJ. Atlantoaxial rotatory fixation. (Fixed rotatory subluxation of the atlantoaxial joint). J Bone Joint Surg Am 1977; 59: 37-44.

22. Phillips WA, Hensinger RN: The management of rotatory atlantoaxial subluxation in children. $\mathrm{J}$ Bone Joint Surg Am 1989; 71: 664-8.

23. Subach BR, McLaughlin MR, Albright AL, Pollack IF. Current management of pediatric atlantoaxial rotatory subluxation. Spine 1998; 23: 2174-9.

24. Pang D, Li V. Atlantoaxial rotatory fixation: part 3-a prospective study of the clinical manifestation, diagnosis, management, and outcome of children with alantoaxial rotatory fixation. Neurosurgery 2005; 57: 954-72.
25. Beier AD, Vachhrajani S, Bayerl $\mathrm{SH}$, Aguilar CY, LambertiPasculli M, Drake JM. Rotatory subluxation: experience from the Hospital for Sick Children. J Neurosurg Pediatr 2012; 9: 144-8.

26. Ciftdemir M, Copuroğlu C, Ozcan M, Ulusam AO, Yalnız E. Nonoperative treatment in children and adolescents with atlantoaxial rotatory subluxation. Balkan Med J 2012; 29: 277-80.

27. Chechik O, Wientroub S, Danino B, Lebel DE, Ovadia D. Successful conservative treatment for neglected rotatory atlantoaxial dislocation. J Pediatr Orthop 2013; 33: 389-92.

28. Karkos PD, Benton J, Leong SC, Mushi E, Sivaji N, Assimakopoulos DA. Grisel's syndrome in otolaryngology: a systematic review. International Journal of Pediatric Otorhinolaryngology $2007 ; \quad 71$ : 1823-7.

29. Deichmueller CM, Welkoborsky HJ. Grisel's syndrome-a rare complication following "small"operations and infections in the ENT region. European Archives of Oto-RhinoLaryngology 2010; 267: 1467-73.

30. Harma A, Firat Y. Grisel syndrome: nontraumatic atlantoaxial rotatory subluxation. Journal of Craniofacial Surgery 2008; 19: 1119-21.

31. Fernandez Cornejo VJ, MartinezLage JF, Piqueras C, Gelabert A, Poza M. Inflammatory atlantoaxial subluxation (Grisel's syndrome) in children: Clinical diagnosis and management. Childs Nerv Syst 2003; 19: 342-7.

32. Dagtekin A, Kara E, Vayisoglu Y, Koseoglu A, Avci E, Talas D, et al. The importance of early diagnosis and appropriate treatment in Grisel's syndrome: report of two cases. Turk Neurosurg 2011; 21: 680-4. 